\title{
PENINGKATAN KEMAHIRAN BERBICARA BAHASA INGGRIS MAHASISWA POLITEKNIK NEGERI JAKARTA MELALUI MAGIC FIVE FINGERS METHOD Supriatnoko ${ }^{1)}$ dan Hastuti Redyanita \\ Jurusan Akuntansi Politeknik Negeri Jakarta

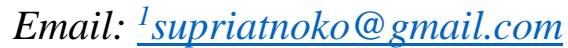

\begin{abstract}
Abstrak
Penelitian PENINGKATAN KEMAHIRAN BERBICARA BAHASA INGGRIS MAHASISWA POLITEKNIK NEGERI JAKARTA MELALUI MAGIC FIVE FINGERS METHOD ini bertujuan untuk meningkatkan kemahiran berbicara bahasa Inggris mahasiswa PNJ khususnya mahasiswa Program Studi Akuntansi dan Program Studi Keuangan dan Perbankan serta untuk meningkatkan kualitas kinerja dosen dalam pembelajaran bahasa Inggris, mengingat sampai saat ini hasil belajar mahasiswa dalam kemahiran berbicara bahasa Inggris masih belum memuaskan. Mencermati metode yang selama ini diterapkan seperti direct method dan grammar translation method belum mampu meningkatkan kemahiran mahasiswa dalam berbicara dengan penuh percaya diri tanpa keraguan. Pentingnya penelitian ini diusulkan, yakni untuk mendukung Renstra dan visi, misi serta tujuan PNJ menjadi politeknik unggul dimana bahasa Inggris menjadi faktor pendukung utama keahlian program studi. Penelitian ini diusulkan pelaksanaannya pada tahun 2017 ini, menggunakan pola penelitian tindakan kelas (PTK) sehingga penelitian bersifat siklis. Data dikumpulkan melalui penggunaan teknik tes lisan berbicara. Tes diberikan sebagai bukti dari proses dan hasil belajar yang telah dilaksanakan pada pokok bahasan yang dipelajari mahasiswa dan dianalisis melalui teknik analisis deskriptif dan teknik analisis kritis. Output berupa hasil penelitian disampaikan dalam seminar nasional/internasional, dan publikasi dalam bentuk jurnal skala nasional. Outcome penelitian berupa bukti kemahiran berbicara yang dimiliki setiap mahasiswa yang telah mengalami treatment sebagai sampel. Dilaksanakan melalui tahapan Pra Siklus, Siklus 1, Siklus 2, Siklus 3. Pada akhir Siklus 3 diperoleh hasil skor nilai sebesar 80.4 dengan jumlah peserta didik yang berhasil mampu membuat kalimat pertanyaan dengan menggunakan verb 1, to be + verb-ing, modal auxiliary will, have/has + verb 3, dan will have + verb3 sebanyak 61 dari jumpal sampel sebanyak 89 orang. Dengan demikian, hipotesis penelitian dapat diterima.
\end{abstract}

Kata Kunci: Kemahiran berbicara, Mahasiswa, Magic Five Fingers, PTK, Siklis

\section{PENDAHULUAN}

Pendekatan komunikatif hampir tigapuluh tahun ini digunakan dalam pembelajaran bahasa Inggris di PNJ, bertujuan agar mahasiswa mampu berkomunikasi dalam bahasa Inggris. Keunggulan pendekatan komunikatif ditemukan pada aspek kognisi membangun ide/gagasan (notion). Hanya saja kelemahan dari pendekatan ini ditemukan pada aspek keterampilan dasar tata bahasa atau grammar, aspek psikologis dan praktis. Masih ditemukan banyak kesalahan tata bahasa yang dibuat mahasiswa ketika menuangkan gagasan ke dalam proses berbicara ataupun menulis bahasa Inggris. Hasilnya, kemahiran menyimak, membaca, berbicara, dan menulis belum memuaskan. Diduga bahwa faktor penyebabnya adalah metode pembelajaran yang digunakan kurang mendukung keberhasilan pendekatan komunikatif. Misalnya penggunaan metode langsung (direct method) yang lebih menekankan kepada penghapalan rumusrumus konstruksi kalimat yang pada waktunya digunakan dalam proses komunikasi, mahasiswa mengalami kesulitan memilah bentuk tenses. Penerapan metode kosakata (vocabulary building) lebih menekankan pada penghapalan kata-kata yang pada waktunya digunakan dalam proses 
komunikasi, mahasiswa mengalami kesulitan mengkonstruksi kalimat. Demikian pula dengan penggunaan metode tata bahasa dan terjemahan (grammar translation method). Metode ini lebih menekankan pada pengalihan bahasa baik dari bahasa Inggris sebagai bahasa sumber ke Bahasa Indonesia sebagai bahasa sasaran ataupun sebaliknya. Kelemahan hasil belajar yang ditemukan dari penggunaan metode-metode tersebut di atas, mahasiswa belum mampu menumbuhkan rasa percaya diri menggunakan bahasa Inggris dalam proses komunikasi lisan ataupun tulisan, yang ditandai adanya perasan takut salah, takut ditertawakan. Oleh sebab itu, Metode Lima Jari atau disebut "Magic Five Fingers Method"diteliti manfaatnya di dalam pembelajaran bahasa Inggris, yakni apakah mampu mampu meningkatkan keterampilan tata bahasa? Apakah mampu meningkatkan kemahiran berbicara bahasa Inggris? dan Berapa persenkah tingkat keberhasilannya?

Metode Lima Jari tergolong metode baru dalam pembelajaran bahasa Inggris, dan parts of speech menjadi fokus pertama yang digali pada pembelajaran bahasa Inggris. Bentuk penelitian yang digunakan adalah bentuk penelitian tindakan kelas (classroom action research). Penelitian tindakan kelas (PTK) bertujuan untuk meningkatkan kinerja dosen/guru serta hasil belajar mahasiswa/siswa. Dengan demikian, penelitian tindakan kelas bertujuan bukan hanya mengungkapkan penyebab dari berbagai permasalahan yang dihadapi tetapi yang lebih penting lagi adalah memberikan solusi berupa tindakan untuk mengatasi permasalahan pembelajaran tersebut. Penelitian tindakan kelas ini menggunakan model Kemmis dan Taggers. Satu ciri khas PTK adalah adanya siklus. Menurut Kemmis dan McTaggart (dalam Pusat Pengembangan Profesi Pendidik BPSDMPK-PMP Kemdikbud RI, 2013), satu siklus terdiri dari empat komponen, yaitu 1) Perencanaan, 2) Pelaksanaan, 3) Pengamatan, dan 4)
Refleksi, dan penelitian ini sedikitnya dilaksanakan dalam tiga siklus.

\section{Tinjauan Pustaka Konsep Dasar PTK}

Dave Ebbutt (dalam Hopkins, 1993), menyatakan bahwa penelitian tindakan adalah kajian sistematis tentang upaya meningkatkan mutu praktik pendidikan oleh sekelompok masyarakat melalui tindakan praktis yang mereka lakukan dan melalui refleksi atas hasil tindakan tersebut. Sementara menurut Kemmis dan McTaggart (dalam Soly Abimanyu, 1995), penelitian tindakan adalah studi yang dilakukan untuk memperbaiki diri sendiri, pengalaman kerja sendiri, tetapi dilaksanakan secara sistematis, terencana, dan dengan sikap mawas diri. Suwandi (2009) menyatakan bahwa sebagai bentuk penelitian praktis, dalam bidang pendidikan, penelitian tindakan ini mengacu pada apa yang dilakukan dosen/guru untuk memperbaiki proses pengajaran yang menjadi tanggung jawabnya. Penelitian ini dapat dilakukan dosen/guru secara perorangan untuk kepentingan perbaikan pengajarannya di kelas atau dilakukan oleh sekelompok atau seluruh dosen/guru untuk memperbaiki keadaan sekolah. Arikunto (2006) menjelaskan frasa penelitian tindakan kelas dari unsur kata pembentuknya, yakni penelitian, tindakan, kelas. Penelitian mengacu pada suatu kegiatan mencermati suatu objek dengan menggunakan cara atau aturan metodologi tertentu untuk memperoleh data atau informasi yang bermanfaat untuk meningkatkan mutu suatu hal yang menarik minat dan penting bagi peneliti. Tindakan mengacu pada suatu gerak kegiatan yang sengaja dilakukan dengan tujuan tertentu. Dalam penelitian tindakan kelas tindakan itu berbentuk rangkaian siklus kegiatan untuk mahasiswa/siswa. Kelas mengacu pada pengertian yang tidak terikat pada ruang kelas, tetapi pada pengertian yang lebih spesifik. Istilah kelas mengacu pada sekelompok mahasiswa/siswa yang dalam 
waktu yang sama menerima pelajaran yang sama dari dosen/guru yang sama. Kelas bukan berupa wujud ruang, tetapi sekelompok peserta didik yang sedang belajar. Dengan demikian, penelitian tindakan kelas dapat dilakukan tidak hanya di ruang kelas, tetapi di mana saja tempatnya, yang penting ada sekelompok mahasiswa/siswa. Pembelajaran dapat terjadi di laboratorium, di perpustakaan, di lapangan olahraga, di tempat kunjungan, atau tempat lain.

PTK merupakan penelitian yang bersifat reflektif. Kegiatan penelitian berangkat dari permasalahan riil yang dihadapi oleh dosen/guru dalam proses belajar mengajar, kemudian direfleksikan alternatif pemecahan masalahnya dan ditindaklanjuti dengan tindakan-tindakan nyata yang terencana dan terukur. Hal penting dalam PTK adalah tindakan nyata (action) yang dilakukan dosen/guru (dan bersama pihak lain) untuk memecahkan masalah yang dihadapi dalam proses belajar mengajar. Tindakan itu harus direncanakan dengan baik dan dapat diukur tingkat keberhasilannya dalam pemecahan masalah tersebut. Jika ternyata program itu belum dapat memecahkan masalah yang ada, maka perlu dilakukan penelitian siklus berikutnya (siklus kedua) untuk mencoba tindakan lain (alternatif pemecahan yang lain sampai permasalahan dapat diatasi).

\section{Karakteristik PTK}

Mengacu pada konsep dasar PTK di atas, beberapa karakteristik PTK antara lain:

1. Masalahnya nyata, tidak dicari-cari, bersifat kontekstual

2. Berorientasi pada pemcahan masalah, bukan hanya mendeskripsikan masalah

3. Data diambil dari berbagai sumber

4. Bersifat siklik: penelitian-tindakan, penelitian-tindakan, dst

5. Partisipatif, dilakukan sendiri

6. Kolaboratif, dibantu rekan sejawat (Pusat Pengembangan Profesi Pendidik
BPSDMPK-PMP Kemdikbud RI, 2013).

\section{Siklus Penelitian}

Satu ciri khas PTK adalah adanya siklus. Menurut Kemmis dan McTaggart (dalam Pusat Pengembangan Profesi Pendidik BPSDMPK-PMP Kemdikbud RI, 2013), siklus terdiri dari empat komponen, yaitu Perencanaan-PelaksanaanPengamatan-Refleksi. Siklus PTK sebenarnya adalah satu satuan penelitian yang lengkap, karena komponenkomponennya lengkap dari perencanaan sampai refleksi. PTK sebaiknya minimal terdiri dari tiga siklus; kalau baru satu siklus sudah berhasil kemungkinan masalahnya terlalu sederhana

\section{Magic Five Finger Method}

Mengapa disebut “LIMA JARI”? Lima jari digunakan sebagai media untuk menstimulasi reaksi otak agar menginstruksikan mulut segera berbicara atau menginstruksikan tangan untuk menulis. "Lima Jari" memanfaatkan STIMULUS dan RESPONS. Ketika seseorang memegang tiap-tiap jari, otak mengirimkan tanda untuk mengujarkan apa yang dilihat secara simultan. Guna memberi penguatan, peserta didik diberi repetition dan dilakukan drilling. Proses repetition dan drilling dilakukan untuk memberi pemahaman bahwa proses berbicara secara alamiah terjadi secara spontan, sehingga tindakan hapalan harus dihindari sejauh mungkin.

METODE "Five Fingers" menggunakan TEKNIK menyusun kalimat pertanyaan dengan berpegangan pada JARI dalam upaya membiasakan mahasiswa untuk berani bertanya dan mengungkapkan apa yang dipikir dan dirasa secara spontan sehingga secara bertahap mampu menggugurkan RASA TAKUT SALAH dan RASA TIDAK PERCAYA DIRI. Secara garis besar, teknik mengajar dengan "Lima Jari” adalah dengan memanfaatkan 5 BENTUK PERTANYAAN, melalui langkah-langkah yang dilakukan: 
1. Menguatkan PARTS OF SPEECH khususnya NOUN, PRONOUN, VERB, ADJECTIVE, ADVERB.

2. Menguatkan pemahaman terhadap SUBJEK KALIMAT dan KATA GANTI (pronoun).

3. Menguatkan 5 bentuk kata Tanya, yaitu dengan WH-QUESTION, YES/NO QUESTIONS, POSITIVE TAG QUESTIONS, NEGATIVE TAG QUESTIONS, dan ASSUMPTION QUESTIONS.

4. Menguatkan 5 JENIS KATA TANYA dengan menggunakan 5 JARI.

Otak, Jari dan Mulut membangun satu jaringan yang kuat untuk menghasilkan 5 jenis kata tanya dengan struktur kalimat yang baik dan benar.

Urutan Kalimat Tanya diawali dengan WH-QUESTION.

Contoh:

Dosen menghadirkan 3 kata, yaitu:

WHAT YOU STUDY

Mahasiswa diminta untuk membuat kalimat tanya dengan menggunakan jari-jari tangan.

JEMPOL :WHAT DO YOU STUDY?

ANSWER: I STUDY ENGLISH

Setelah diperoleh kalimat tanya dengan benar dilanjutkan membuat kalimat pertanyaan lain dengan menggunakan jari telunjuk dan seterusnya.

JEMPOL : WHAT DO YOU STUDY?

TELUNJUK : DO

YOU STUDY ENGLISH?

JARI TENGAH :

YOU STUDY ENGLISH, DON'T YOU?

JARI MANIS :

YOU DON'T STUDY ENGLISH, DO YOU?

TELUNJUK :

YOU STUDY ENGLISH?

5. Menguatkan satu persatu dari 5 jenis pertanyaan dengan media 5 jari.
6. Menguatkan konstruksi kalimat B A S S S A

7. Menguatkan target waktu CAPAIAN 5 DETIK untuk mengujarkan 5 jenis pertanyaan dan 10 detik untuk TANYA JAWAB singkat.

Pengukuran (Assessment) dan Evaluasi disampaikan melalui praktik berbicara, Pengukuran dan Evaluasi dapat juga diberikan melalui sejumlah item pertanyaan untuk dijawab secara tertulis. Komponen Pengukuran dan Evaluasi praktik berbicara, yaitu pronunciation, fluency, notion accuracy, vocabulary, grammar. Sementara komponen untuk tes menulis adalah graphology, punctuation, notion accuracy, vocabulary, grammar.

\section{METODE PENELITIAN}

Penelitian ini dilaksanakan di Politeknik Negeri Jakarta, berlangsung selama 8 bulan. Rincian kegiatan penelitian tersebut adalah: persiapan penelitian, koordinasi persiapan tindakan, pelaksanaan (perencanaan, tindakan, monitoring dan evaluasi, dan refleksi), penyusunan laporan penelitian, penggandaan, pengiriman laporan penelitian, dan publikasi. Penelitian ini menggunakan metode penelitian tindakan kelas (PTK) dengan model Kemmis \& Taggart dengan tahapan siklus: perencanaan, pelaksanaan, pengamatan, dan refleksi. Magic Five Fingers Method menjadi variabel yang diteliti.

Subjek penelitian adalah mahasiswa dan dosen yang terlibat dalam pelaksanaan pembelajaran. Lokasi penelitian tindakan kelas ini dilakukan di kelas yang diampu peneliti berjumlah 3 kelas di Jurusan Akuntansi. Peneliti sebagai dosen yang mengajar mengaplikasikan Magic Five Fingers Method sekaligus mengamati output dan outcome dari pelaksanaannya, sebagai variabel bebas atau tindakan dalam PTK, dan pada akhir pembelajaran diadakan diskusi singkat. Pada akhir minggu pertemuan peneliti menganalisis 
keberhasilan dan kegagalan penelitian dalam satu minggu, dan merencanakan tindakan untuk minggu berikutnya.

Data penelitian yang dikumpulkan berupa informasi tentang proses dan hasil pembelajaran bahasa Inggris, berupa aktifitas mahasiswa, kemampuan mahasiswa dalam berbicara, serta kemampuan dosen dalam menyusun rencana pembelajaran dan melaksanakan pembelajaran di kelas. Data penelitian ini dikumpulkan dari berbagai sumber yang meliputi:

1. informan atau nara sumber, yaitu mahasiswa dan dosen

2. Tempat dan peristiwa berlangsungnya aktivitas pembelajaran bahasa bahasa Inggris

3. Dokumen atau arsip, yang antara lain berupa kurikulum, RPS, hasil pekerjaan mahasiswa, dan buku penilaian.

Teknik yang digunakan untuk mengumpulkan data meliputi pengamatan, wawancara atau diskusi, dan tes hasil belajar. Tes hasil belajar dirinci ke dalam tujuh komponen, yaitu menginterpretasi, (2) memberi contoh, (3) mengklasifikasi, (4) merangkum, (5) menginferensi, (6) membandingkan, (7) menjelaskan. Pedoman wawancara dengan mahasiswa disiapkan, demikian juga lembar pengamatan dan catatan lapangan. Pedoman-pedoman itu dibuat berdasarkan kisi-kisi untuk menjamin validitas-isi, dan kisi-kisi dibuat berdasarkan teori yang dibahas di kajian pustaka. Singkatnya, "instrumen harus dibuat berdasarkan kisikisi, dan kisi-kisi dibuat berdasarkan teori”. Instrumen dalam PTK adalah alat untuk mengukur keberhasilan tindakan pada variabel yang ingin ditingkatkan, yaitu kemahiran berbicara bahasa Inggris mahasiswa.

Validitas data harus reliabel dan ajeg, yaitu jika digunakan dengan cara yang sama hasilnya akan sama. Teknik yang digunakan dalam PTK untuk memeriksa validitas data didekati dengan teknik triangulasi dan review informasi kunci.
Artinya satu variabel terikat diukur dengan beberapa instrumen. Misalnya, untuk mengetahui kesulitan-kesulitan yang dihadapi mahasiswa dalam berbicara bahasa Inggris dan faktor-faktor penyebabnya, peneliti tidak cukup hanya dengan memberikan tes tertulis, melainkan juga melakukan wawancara, dan pengamatan.

Indikator kinerja sebagai toloh ukur keberhasilan penelitian ini adalah skor rata-rata kelas mencapai 80 , yang disebut Kriteria Ketuntasan Minimal (KKM). Siklus "perencanaan-pelaksanaanpengamatan-refleksi "plan-act-observereflect” akan terus berlangsung sampai kriteria keberhasilannya tercapai.

Penelitian direncanakan berlangsung selama tiga siklus, yang masing-masing terdiri dari: perencanaan (plan), pelaksanaan (act), pengamatan (observe), dan refleksi (reflect). Tiga siklus direncanakan dalam waktu selama 8 minggu sehingga keseluruhan penelitian akan terdiri dari sekitar delapan pertemuan tatap muka (@4 jam pelajaran). Perencanaan tidak lain adalah hipotesis tindakan, dilaksanakan secara berulangulang dalam Siklus I, sebanyak tiga kali pertemuan tatap muka. Pelaksanaan tindakan diamati dan dicatat dengan seksama. Pada akhir siklus pengamatan terhadap variabel terikat dilakukan tes. Data hasil tes dianalisis atau direfleksi untuk mengetahui keberhasilan atau kegagalannya. Refleksi diakhiri dengan merencanakan tindakan alternatif atau revised plan, yang akan diterapkan pada siklus II. Perencanaan untuk Siklus II sepenuhnya tergantung pada hasil refleksi Siklus I; demikian juga perencanaan untuk Siklus III sepenuhnya tergantung pada hasil refleksi Siklus II.

Data penelitian yang telah dikumpulkan dianalisis dengan teknik statistik deskriptif dan teknik analisis kritis. Teknik statistik deskriptif digunakan untuk data kualitatif, yakni dengan membandingkan hasil antarsiklus. Peneliti membandingkan hasil sebelum penelitian dengan hasil pada akhir 
setiap siklus. Teknik analisis kritis berkaitan dengan data kualitatif. Teknik analisis kritis mencakup kegiatan untuk mengungkap kelemahan dan kelebihan kinerja mahasiswa dan dosen dalam proses belajar mengajar berdasarkan kriteria normatif yang diturunkan dari kajian teoritis maupun dari kriteria keberhasilan. Hasil analisis tersebut dijadikan dasar dalam menyusun perencanaan tindakan untuk tahap berikutnya sesuai siklus yang ada. Analisis data dilakukan bersamaan dan/atau setelah pengumpulan data (Suwandi, 2010: 61). Hasil analisis data disajikan secara deskriptif. Dimaksud dengan penyajian secara deskriptif, yaitu hasil analisis data dipaparkan secara jelas dan rinci dengan menggunakan terminologi yang bersifat teknis.

\section{HASIL DAN PEMBAHASAN Deskripsi PerSiklus}

Peneliti / praktikan dan mahasiswa berstatus responden atau informan. Hasil praktik berbicara mahasiswa merupakan data, dokumen sumber informasi mengenai masalah penelitian, sedangkan peristiwa pembelajaran menggambarkan situasi dan kondisi yang sedang berlangsung dan dapat dibaca untuk memahami berbagai aspek pelaksanaan pola asuh dosen.

Hasil penelitian dan pembahasan sampai dengan pelaksanaan perbaikan pembelajaran yang telah dilaksanakan sebanyak 3 siklus pada rentang waktu yang berbeda. Sebelum melakukan perbaikan, peneliti mengobservasi dan mengidentifikasi permasalahan yang dihadapi kelas, selanjutnya melakukan pengumpulan data.

Data diperoleh melalui teknik observasi dan pemberian tugas dialog pada PraSiklus, Siklus 1, Siklus 2, dan Siklus 3 guna menemukan permasalahan di kelas. Berdasarkan observasi yang dilakukan pada PraSiklus, keterampilan berbicara dengan batasan waktu tidak lebih dari 5 detik dan 10 detik masih mengalami kendala, yaitu peserta didik belum mampu berbicara jelas dan cepat menyampaikan pertanyaan dalam waktu yang singkat itu. Penyebabnya karena mereka belum memahami ciri-ciri penggunaan kata bantu pada 5 jenis kalimat pertanyaan dari satu bentuk konstruksi kalimat yang mengungkapkan situasi pada peristiwa "kebiasaan”, pada peristiwa "rencana yang akan dilakukan", dan pada peristiwa "yang hampir dilakukan dengan segera”. Dari hasil pengumpulan data, peneliti mendapatkan data sampel mahasiswa semester satu sebanyak 60 orang berasal dari Jurusan Akuntansi.

\section{Penerapan PraSiklus}

Berikut ini deskripsi dari tiap siklus pada kegiatan berbicara peserta didik semester satu, dari sebelum perbaikan pembelajaran sampai dengan perbaikan Siklus 1, Siklus 2, dan Siklus 3, melalui urutan kegiatan: perencanaan, tindakan, observasi, refleksi.

\section{Perencanaan PraSiklus}

Untuk melaksanakan perencanaan penelitian, pertama kali yang dilakukan peneliti adalah:

1. Menyusun RPS dan SAP.

2. Peneliti mengajak mahasiswa untuk mencari dan mendapatkan kosakata benda, ganti, kerja, sifat, depan dari media anggota tubuh.

3. Peneliti meminta mahasiswa kerja kelompok (satu kelompok terdiri dua orang) untuk mencari dan mendapatkan sebanyak-banyaknya kosakata dan didata diberi nomor pada lembaran kertas.

\section{Tindakan PraSiklus}

Pada tahap ini dilakukan implementasi tindakan, yaitu:

1. Peneliti membuka kegiatan pembelajaran dengan mengucapkan salam.

2. Peneliti memotivasi mahasiswa untuk mengeksplorasi kosakata dari beberapa jenis kata (kata benda, kata ganti, kata kerja, kata sifat, kata 
depan) bersumber pada media anggota tubuh.

3. Peneliti meminta mahasiswa untuk menyebutkan satu persatu leksikal kata benda dari anggota tubuh, dilanjutkan ke pencarian kata ganti dari benda-benda jamak dan tunggal, pindah ke pencarian kata kerja sebanyak-banyaknya dari fungsi kerja tiap anggota tubuh yang disebutkan, pindah ke pencarian kata sifat dari hasil penggunaan kata kerja, dan kata depan yang mungkin dapat digunakan.

4. Sambil memperlihatkan 5 jari tangan kiri, peneliti memperkenalkan satu persatu jari tangan kiri mulai dari jempol. Jempol pengingat untuk bertanya dengan menggunakan kata tanya WH-Q (WH-QUESTIONS), telunjuk pengingat untuk bertanya dengan menggunakan kata tanya YES/NO QUESTIONS, jari tengah pengingat untuk bertanya dengan menggunakan kata tanya QUESTION TAG POSITIVE, jari manis pengingat untuk bertanya dengan menggunakan kata tanya QUESTION TAG NEGATIVE, kelingking pengingat untuk bertanya dengan menggunakan kalimat positif nada bertanya (ASSUMPTION QUESTION).

5. Sebagai re-kreasi, peneliti memberikan contoh dan mahasiswa berlatih membuat 5 pertanyaan secara perorangan dan bertanya jawab dengan menggunakan 5 pertanyaan secara berpasangan.

\section{Pengamatan PraSiklus}

Peneliti memberikan contoh dan meminta peserta didik untuk praktik membuat pertanyaan dengan menggunakan 5 jari tangan kiri. Kegiatan PraSiklus ini menitikberatkan pada kegiatan orientasi dan re-kreasi terhadap kemampuan awal peserta didik membuat pertanyaan lisan sehingga langkah pengamatan dilakukan. Hasil membuat pertanyaan lisan dengan 5 jari diperoleh rata-rata sebesar 6.9 detik, dan tanya jawab berpasangan dengan 5 jari diperoleh rata-rata 12 detik. Pada PraSiklus ini item lain seperti fluency, pronunciation, vocabulary dan sentence construction belum dinilai, karena mereka masih kesulitan menerapkan kata bantu (do/does, is/am/are, will, have/has, will have) pada 5 kalimat pertanyaan yang mereka sampaikan secara lisan dalam waktu relative singkat, yaitu 5 dan 10 detik. Nilai capaian rata-rata 67.4 .

\section{Refleksi PraSiklus}

Kegiatan refleksi PraSiklus masih bersifat orientasi dan pengamatan untuk menemukan masalah yang dihadapi mahasiswa sehingga peneliti belum melaksanakan perbaikan. Dari hasil pengamatan ditemukan 78 mahasiswa atau 88\% belum mampu berbicara lancar dalam waktu maksimal 5 dan 10 detik. Kesulitan yang ditemukan dari sisi mahasiswa yakni ketika membuat pertanyaan yang berkaitan dengan konstruksi kalimat yang menggunakan Verb 1 (present tense). Dari sisi dosen, yakni dosen kurang memotivasi mahasiswa untuk berlatih membuat pertanyaan secara lisan.

\section{Penerapan Siklus 1 \\ Perencanaan Siklus 1}

Berdasarkan hasil PraSiklus kemampuan mahasiswa perlu ditingkatkan melalui langkah eksplorasi, interpretasi, praktik langsung sehingga tujuan melancarkan berbicara dengan ketepatan konstruksi kalimat dapat dicapai.

Pada Siklus 1 dilaksanakan perencanaan kembali sebagai perbaikan dari pra siklus. Adapun perencanaan Siklus 1 adalah:

1. Menyusun RPS dan SAP

2. Peneliti melakukan interaksi melalui kosakata kerja untuk dibuatkan ke dalam kalimat tanya dengan menggunakan 5 jari

3. Peneliti meminta mahasiswa berlatih membuat kalimat bertanya dengan 5 jari secara lisan dengan waktu maksimal yang sudah ditentukan. 
4. Peneliti meminta mahasiswa mempraktikkan kalimat Tanya dengan 5 jari dan melakukan percakapan berupa tanya jawab, dan dilakukan pengukuran waktu.

\section{Tindakan Siklus 1}

Bila tindakan pada PraSiklus dilakukan memberi contoh beberapa kata kerja yang kemudian dibuatkan ke dalam kalimat bertanya dengan menggunakan 5 jari, pada Siklus 1 peneliti melakukan implementasi tindakan sebagai berikut:

1. peneliti membuka kegiatan pembelajaran dengan mengucapkan salam

2. Peneliti memotivasi mahasiswa untuk menemukan kata kerja yang berkaitan dengan profesi

3. Peneliti meminta mahasiswa untuk membuat kalimat tanya dengan menggunakan 5 jari pada kata kerja yang telah ditemukannya dan mencarikan jawabannya.

4. Peneliti meminta mahasiswa untuk berpasangan saling bertanya dengan menggunakan kalimat masing-masing

5. Peneliti memperhatikan cara kerja mahasiswa dalam menyusun kalimat pertanyaan dan kalimat jawabannya

6. Sebagai re-kreasi peneliti mengases mahasiswa uuntuk berpraktik menyampaikan kalimat pertanyaan lisan dengan menggunakan 5 jari dengan batas waktu yang sudah ditentukan.

\section{Pengamatan Siklus 1}

Pada siklus 1 peneliti sepenuhnya melibatkan mahasiswa dalam keaktifan kelas. Mahasiswa melakukan eksplorasi dan menyusun kalimat pertanyaan secara lisan dengan 5 jari. Pada siklus ini tampak peningkatan kemampuan mahasiswa dalam memahami filosofis mengapa membuat pertanyaan dengan 5 jari. Nilai capaian rata-rata sebesar 76.2.

\section{Refleksi Siklus 1}

Pada siklus sebelumnya dititkberatkan pada kegiatan orientasi dan re-kreasi terhadap kemampuan awal mahasiswa. Pada siklus 1 ini mahasiswa tampak mulai memahami penggunaan 5 jari untuk menggeksplorasi kata kerja menjadi kalimat bertanya. Sejumlah 54 mahasiswa belum mampu berbicara lancar dalam waktu maksimal 5 dan 10 detik. Dari hasil pengamatan ditemukan capaian skor ratarata 76.2. Kesulitan yang ditemukan dari sisi mahasiswa yakni ketika membuat kalimat pertanyaan yang berkaitan dengan konstruksi kalimat yang menggunakan modal will, peserta didik masih menggunakan kata bantu do/does. Dari sisi dosen, yakni dosen kurang memotivasi mahasiswa untuk berlatih membuat pertanyaan secara lisan.

\section{Penerapan Siklus 2}

\section{Perencanaan Siklus 2}

Pada Siklus 2 dilaksanakan perencanaan kembali sebagai perbaikan Siklus 1. Adapun perencanaan Siklus 2 adalah

1. Menyusun RPS dan SAP

2. Peneliti melakukan interaksi dengan menyampaikan kalimat pertanyaan kepada mahasiswa secara random.

3. Mahasiswa diminta untuk menjawab dengan konstruksi kalimat yang sesuai.

4. Sebagai re-kreasi peneliti meminta mahasiswa untuk secara berantai menyampaikan pertanyaan lisan dan menjawab dengan 5 jari dengan waktu maksimal yang sudah ditentukan.

\section{Tindakan Siklus 2}

Pada Siklus 2 peneliti melakukan implementasi tindakan dengan memotivasi mahasiswa melakukan eksplorasi dan melatih membuat kalimat pertanyaan dengan 5 jari dan memberi jawabannya sesuai konstruksi kalimat pada kalimat pertanyaan. 


\section{Pengamatan Siklus 2}

Pada Siklus 2 peneliti sepenuhnya melibatkan mahasiswa dalam keaktifan kelas. Mahasiswa melakukan eksplorasi dan menyusun kalimat pertanyaan secara lisan dengan 5 jari. Pada siklus ini tampak peningkatan kemampuan mahasiswa dalam membuat pertanyaan dengan 5 jari. Dari hasil pengamatan ditemukan capaian skor rata-rata 76.4. Nilai capaian rata-rata belum memenuhi indikator capaian ratarata hasil belajar 80 .

\section{Refleksi Siklus 2}

Pada penelitian Siklus 2 peneliti masih melaksanakan langkah eksplorasi, interpretasi, dan re-kreasi dengan memberikan tugas berupa praktik berpasangan membuat Tanya jawab dengan 5 jari bersifat terstruktur.

\section{Penerapan Siklus 3}

\section{Perencanaan Siklus 3}

Pada siklus 3 dilaksanakan perencanaan kembali sebagai perbaikan Siklus 1 . Adapun perencanaan Siklus 3 adalah

1. Menyusun RPS dan SAP

2. Peneliti melakukan interaksi dengan menyampaikan kalimat pertanyaan kepada mahasiswa secara random.

3. Mahasiswa diminta untuk menjawab dengan konstruksi kalimat yang sesuai.

4. Sebagai re-kreasi peneliti meminta mahasiswa untuk secara berantai menyampaikan pertanyaan lisan dan menjawab dengan 5 jari dengan waktu maksimal yang sudah ditentukan.

\section{Tindakan Siklus 3}

Pada Siklus 3 peneliti melakukan implementasi tindakan dengan membiasakan mahasiswa melakukan eksplorasi dan melatih membuat kalimat pertanyaan dengan 5 jari dan memberi jawabannya sesuai konstruksi kalimat pada kalimat pertanyaan.

\section{Pengamatan Siklus 3}

Pada siklus 3 peneliti sepenuhnya melibatkan mahasiswa dalam keaktifan kelas. Mahasiswa melakukan eksplorasi dan menyusun kalimat pertanyaan secara lisan dengan 5 jari. Pada siklus ini tampak peningkatan kemampuan mahasiswa dalam membuat pertanyaan dengan 5 jari. Dari hasil pengamatan ditemukan capaian skor rata-rata 80.4. Nilai capaian rata-rata memenuhi indikator capaian rata-rata hasil belajar 80 .

\section{Refleksi Siklus 3}

Pada penelitian Siklus 3 peneliti masih melaksanakan langkah eksplorasi, interpretasi, dan re-kreasi dengan memberikan kebebasan untuk menentukan bentuk konstruksi kalimat yang akan dibuatkan pertanyaan. Hasil pembelajaran pada Siklus 3 mengalami perkembangan yang baik, hampir semua mahasiswa mampu membuat kalimat pertanyaan dengan konstruksi kalimat yang berbeda. Ditemukan 27 orang mendapat skor dibawah 80 dan 62 orang mendapat skor di atas 80 .

\section{Pembahasan PraSiklus}

Pada PraSiklus dari 89 mahasiswa yang mencapai skor nilai di atas 80 sebanyak 11 orang sedangkan yang mendapat skor nilai dibawah 80 sebanyak 78 orang. Banyaknya mahasiswa yang mendapat skor nilai dibawah 80 disebabkan oleh ketidakbiasaan mereka untuk membuat kalimat pertanyaan dengan berbagai jenis pertanyaan dengan waktu yang sangat dibatasi.

\section{Siklus 1}

Setelah diberikan pembelajaran melalui langkah orientasi, eksplorasi, dan interpretasi melalui tanya jawab, dilanjutkan praktik. Pada siklus 1 ditemukan mahasiswa yang masih kesulitan berbicara menyampaikan kalimat pertanyaan dalam waktu yang dibatasi dengan konstruksi kalimat yang benar. 
Pada Siklus 1 dari 89 mahasiswa yang mencapai skor nilai di atas 80 sebanyak 38 orang sedangkan yang mendapat skor nilai dibawah 80 sebanyak 51 orang.

\section{Siklus 2}

Setelah diberikan pembelajaran melalui langkah orientasi, eksplorasi, dan interpretasi melalui tanya jawab, dilanjutkan praktik. Pada siklus 2 ditemukan mahasiswa yang masih kesulitan berbicara menyampaikan kalimat pertanyaan dalam waktu yang dibatasi dengan konstruksi kalimat yang benar. Pada Siklus 2 dari 89 mahasiswa yang mencapai skor nilai di atas 80 sebanyak 57 orang sedangkan yang mendapat skor nilai dibawah 80 sebanyak 32 orang.

\section{Siklus 3}

Berdasarkan hasil perbaikan dengan memperhatikan kelemahan dan kekurangan pada Siklus 1, Siklus 2, maka pada Siklus 3 mahasiswa yang memahami konsep 5 jari dalam membuat kalimat pertanyaan mengalamii peningkatan signifikan. Dari 89 mahasiswa, yang mendapat skor nilai di atasi 80 sebanyak 61 orang dan yang masih mendapat skor nilai dibawah 80 sebanyak 28 orang dengan skor nilai rata-rata yang dicapai sebesar 80.4.

Berdasarkan skor nilai rata-rata yang dicapai, hipotesis tindakan atau hipotesis kerja dinyatakan “diterima”. Hal ini berarti penggunaan Magic Five Fingers Method mampu meningkatkan kemampuan mahasiswa dalam membuat kalimatkalimat pertanyaan dan jawaban. Penggunaan Magic Five Fingers Method mampu meningkatkan kemahiran berbicara bahasa Inggris.

\section{KESIMPULAN DAN SARAN Kesimpulan}

Berdasarkan hasil temuan dalam penelitian ini, peneliti mengambil kesimpulan bahwa :
Method mampu meningkatkan kemampuan mahasiswa dalam membuat kalimat-kalimat pertanyaan dan jawaban.

2. Penggunaan Magic Five Fingers Method mampu meningkatkan kemahiran berbicara bahasa Inggris.

3. Setelah diberikan Siklus 3, skor nilai rata-rata mampu mencapai skor indikator yang ditetapkan walaupun ditemukan 61 peserta didik mampu mencapai skor nilai di atas 80 .

4. Kelemahan yang ditemukan, yaitu mahasiswa belum terbiasa untuk berlatih berbicara cepat, benar secara konstruksi kalimat dan tepat secara maksud.

\section{Saran}

1. Berdasarkan kesimpulan tersebut di atas, peneliti mengajukan saran bahwa pembelajaran bahasa Inggris dengan menggunakan metode 5 jari harus dimulai dengan men-drilling kosa kata melalui mengenalan dan eksplorasi jenis kata dasar, yaitu kosa kata nomina, kata ganti, verba, ajektifa, dan preposisi.

2. Berdasarkan pengamatan hasil penelitian ditemukan perbedaan kemampuan dasar bahasa Inggris antara mahasiswa program Studi Akuntansi dan mahasiswa Program Studi Keuangan dan Perbankan, sehingga harus diberikan treatment dan penguatan yang berbeda di dalam pembelajaran bahasa Inggris.

\section{DAFTAR PUSTAKA}

Ahmad, Syaban. 2017. Magic Five Fingers. Wawancara dengan Syaban Sang pencipta.

Arikunto, Suharsimi, Suhardjono, dan Supardi. 2006. Penelitian Tindakan Kelas. Jakarta: Bumi Aksara. 
Daniati, Rahmi. 2016. Teaching Question Sentences by Using Five Fingers Technique: An Experimental Study at MTs Meuraxa Banda Aceh. Skripsi. Banda Aceh: Universitas Syiah Kuala.

Departemen Pendidikan Nasional RI. 2008. Kamus Besar Bahasa Indonesia. Jakarta: Balai Pustaka.

Hamalik, Oemar, 2008. Perencanaan Pengajaran Berdasarkan Pendekatan Sistem. Jakarta: Bumi Aksara.

Hopkins, David. 1993. A Teacher's Guide to Classroom Research. Second edition. Philadelphia: Open University Press.

Karwono dan Mularsih. 2010. Belajar dan Pembelajaran serta Peanfaatan Sumber Belajar. Jakarta: Cerdas Jaya.

PNJ. 2014. Buku Profil Politeknik Negeri Jakarta. Depok.

PNJ. 2015. Rencana Strategis (Renstra) 2015-2019 PNJ menjadi Politeknik Kelas Asia Tenggara. Depok.

Soly Abimanyu dkk. 1995. Penelitian Praktis untuk Perbaikan Pengajaran. Jakarta: Bagian Proyek PGSD Ditjen Dikti Depdikbud RI.

Supriatnoko dan Anwar Mustofa. 2016. Penerapan Model Pembelajaran Kreatif Produktif Pada Mata Kuliiah Bahasa Inggris di Politeknik Negeri Jakarta. Hasil Penelitian dalam Epigram Volume 13 Nomor 2 Oktober 2016.

Suprijono, Agus. 2011. Model-model Pembelajaran. Jakarta: Gramedia Pustaka Jaya.

Suwandi, Sarwiji. 2010. Penelitian Tindakan Kelas (PTK) dan Penulisan Karya Ilmiah. Surakarta: Yuma Pustaka.

UU RI Nomor 20 Tahun 2003 tentang Sistem Pendidikan Nasional. 
